Article

\title{
Data Analysis of Land Use Change and Urban and Rural Impacts in Lagos State, Nigeria
}

\author{
Olalekan O. Onilude ${ }^{1}$ and Eric Vaz ${ }^{2, *}$ \\ 1 Environmental Applied Science and Management-Yeates School of Graduate Studies, Ryerson University, \\ Toronto, ON M5B 2K3, Canada; oonilude@ryerson.ca \\ 2 Department of Geography and Environmental Studies, Ryerson University, Toronto, ON M5B 2K3, Canada \\ * Correspondence: evaz@ryerson.ca
}

Received: 20 May 2020; Accepted: 9 August 2020; Published: 11 August 2020

\begin{abstract}
This study examines land use change and impacts on urban and rural activity in Lagos State, Nigeria. To achieve this, multi-temporal land use and land cover (LULC) datasets derived from the GlobeLand30 product of years 2000 and 2010 for urban and rural areas of Lagos State were imported into ArcMap 10.6 and converted to raster files (raster thematic maps) for spatial analysis in the FRAGSTATS situated in the Patch Analyst. Thus, different landscape metrics were computed to generate statistical results. The results have shown that fragmentation of cultivated lands increased in the rural areas but decreased in the urban areas. Also, the findings display that land-use change resulted in incremental fragmentation of forest in the urban areas, and reduction in the rural areas. The fragmentation measure of diversity increased in the urban areas, while it decreased in the rural areas during the period of study. These results suggest that cultivated land fragmentation is a complex process connected with socio-economic trends at regional and local levels. In addition, this study has shown that landscape metrics can be used to understand the spatial pattern of LULC change in an urban-rural context. Finally, the outcomes of this study will help the policymakers at the three levels of governments in Nigeria to make crucial informed decisions about sustainable land use.
\end{abstract}

Keywords: land use change; urban-rural areas; geographic information systems; landscape metrics; Lagos State; Nigeria

\section{Summary}

Land use changes and urbanization have altered the landscape patterns of urban areas [1] due to substantial growth experienced by these areas in recent years [2,3]. The change in the landscape pattern is substantially caused by natural and human factors [4-7]. The results of changes in landscape patterns through human activities (e.g., population increase, urban sprawl, and agriculture) can affect the ecosystem [8] and alter the relationships between people and their natural environment [9-11]. The concepts of 'urban and rural' have been manifested in land use change and urbanization research. An urban area can be defined as a region within the jurisdiction of a city. It can refer to cities or suburbs with a high population density where most inhabitants are not mainly engaged in agriculture [12]. Rural areas have low population density and large quantities of undeveloped land [13], and they are the main service providing units for urban areas, as they provide an environment-based livelihood for people [14]. Thus, the 'rural-urban divide' forms the basis for policymaking in most of the developing countries [15]. Urbanization does not only deal with land-use change but also with lifestyle changes that concern rural-urban relationships in agriculture [16]. Similarly, the expansion of urban areas and continued sprawl is negatively affecting our environment and natural rural landscapes [17-19]. Subsequently, this can lead to contamination of soil, water, and air [20] and greenhouse gas emissions in urban-rural environments [21]. 
Landscapes comprise of patches that are natural or altered by few human influences. These patches differ in their sizes, shapes, and arrays [22]. Rural landscapes are the effect of a dynamic process motivated by environmental and anthropogenic factors [23,24]. Landscape metrics are tools extensively used for analyzing [25], monitoring, and planning of landscape patterns [26]. These metrics are often used to analyze the spatial changes in the composition and configuration of landscapes [27]. Also, analyses such as fragmentation, diversity, changes in landscape patterns, and descriptions of the landscape structure are offered by landscape metrics. Besides, other techniques such as Remote Sensing (RS), Geographic Information System (GIS), land-use models, and statistical approaches have been used to examine changes in landscape patterns [28-31].

Urban growth in developing countries is diverse and alarming. As well, the residential and industrial incursions of growing urban areas lead to a constant decrease of high-quality agricultural land and forests in the marginal areas of cities and in rural areas [32,33]. Research shows an overall trend of declines in farmland during urbanization in many regions around the world [34-39]. From a regional context, semi-natural land reveals a decreasing trend, principally because of agricultural progression [40-42]. In Nigeria, studies that concern the mapping of urban growth, land use change and incursion into the rural lands include the following: A study was conducted by Dekolo, Oduwaye, and Nwokoro [43] using a multi-temporal RS and GIS analysis to find out urban sprawl and loss of agricultural land over a 40-year period in Ikorodu municipality, Lagos State. Findings display that agricultural lands were reduced by a significant amount of $25 \%$, and this correlates with rapid urban changes. Olayiwola and Igbavboa [44] applied remotely sensed data to examine the trend of urban growth and its consequence on the land use pattern in Benin City, Nigeria. Research findings showed that the expansion of Benin City resulted in an inverse spillover effect on the vegetation resources of the adjoining rural settlements.

Landscape fragmentation is a process that brings about habitat loss and size reduction [45]; its main causes include agricultural growth, infrastructural projects, e.g., road construction, and urban sprawl [46]. Unrestrained urban expansion resulted in fragmentation of landscapes, destruction of wildlife habitat, and a decrease in biodiversity [47]. Several landscape metrics have been reported for quantifying the spatial patterns of landscapes at regional or local scales over the past years [48-55]. For instance, Crews-Meyer [56,57] used landscape metrics to evaluate the stability of agricultural land through the adoption of farmland patches as the elementary analytical element. Also, Southworth et al. [58] applied landscape metrics to pixel-based change trajectories to evaluate the degree of fragmentation of forest land cover over three periods. As well, Vaz et al. [12] employed landscape metrics to analyze the impacts of agricultural land changes and connection of tourism growth on these changes in Algarve, Portugal. Research findings showed an increase in urbanization while agriculture decreased significantly in Algarve between 1990 and 2006, which subsequently disturb the equilibrium of the environment [12]. The study by Luck and Wu [59] on gradient analysis of the urban landscape pattern in Phoenix, USA showed that landscape metrics are suitable to identify changes in land use from urban to rural environments. Thus, the benefit of landscape metrics for analyzing agricultural and socio-economic changes is extremely closely connected to the possibility of realizing the changing aspects of land use [60].

Much work has been accomplished using landscape metrics and remote sensing; however, little research has been concentrated on land use change and impacts on urban and rural activity in Lagos State using these tools. Therefore, this study seeks to understand if urban sprawl is altering rural landscape of the Lagos State, Nigeria. Likewise, the primary objective is to investigate land use change and impacts on urban and rural areas. The study specifically intends to (1) characterize landscape pattern changes across Lagos State from 2000 to 2010; and (2) quantify the impacts of land use change on the landscape structure of urban and rural areas using landscape metrics. 


\section{Study Area}

The study area is Lagos State, which is situated in the low-lying coastal region of South West Nigeria. It is geographically situated on longitudes $2^{\circ} 42^{\prime}-4^{\circ} 20^{\prime}$ E and latitudes $6^{\circ} 22^{\prime}-6^{\circ} 42^{\prime} \mathrm{N}$. The State is bordered on the west by the Republic of Benin and on the north and east by Ogun State of Nigeria, as well as the Atlantic coast as its southern boundary. Lagos State is the most populous state in Nigeria with 9,113,605 residents in 2006 (see Table 1), which represented about $6.44 \%$ of the total population of Nigeria [61]. Through land area, Lagos State is the smallest in size in the country with $3577 \mathrm{~km}^{2}$ or 357,700 hectares of land and $779 \mathrm{~km}^{2}$ waterbodies.

Table 1. Population of Lagos State using the urban and rural concepts.

\begin{tabular}{ccccc}
\hline Census Year & Area $\mathbf{( k m}^{\mathbf{2}} \mathbf{)}$ & Urban & Rural/Suburban & Total \\
\hline 1963 & 69.95 & 665,246 & 778,321 & $1,443,567$ \\
1991 & 3577 & $5,260,771$ & 425,010 & $5,685,781$ \\
2006 & 3577 & $7,937,932$ & $1,175,673$ & $9,113,605$ \\
\hline
\end{tabular}

Source: Population of Nigeria, 1963, Lagos Vol. 1 \& 2, National Population Census, 1991; National Population Census, 2006.

There are 20 Local Government Areas (LGAs) in Lagos State. For the purpose of this study, these LGAs were divided into two sections: the urban (metropolitan); and the rural. The urban segment contains 16 LGAs: (1) Agege; (2) Ifako-Ijaye; (3) Alimosho; (4) Ikeja; (5) Shomolu; (6) Kosofe; (9) Oshodi-Isolo; (10) Mushin; (12) Ojo; (13) Amuwo-Odofin; (14) Ajeromi-Ifelodun; (15) Surulere; (16) Lagos Mainland; (17) Lagos Island; (18) Apapa; and (19) Eti-Osa which covers approximately $90 \%$ of the state's total population [62]. Also, the four rural LGAs comprise (7) Ikorodu; (8) Epe; (11) Badagry; and (20) Ibeju-Lekki (see Figure 1); they are recognized as peri-urban settlements because they are located outside the metropolitan region of Lagos State. Furthermore, Lagos State experiences the typical tropical rainforest climate of southern Nigeria with very high temperatures and humidity throughout the year. There are two main seasons: a wet season which occurs from April to November, and a dry season which happens from December to March. The wet and dry seasons are also accompanied by Harmattan dry winds between December and early February of every year.

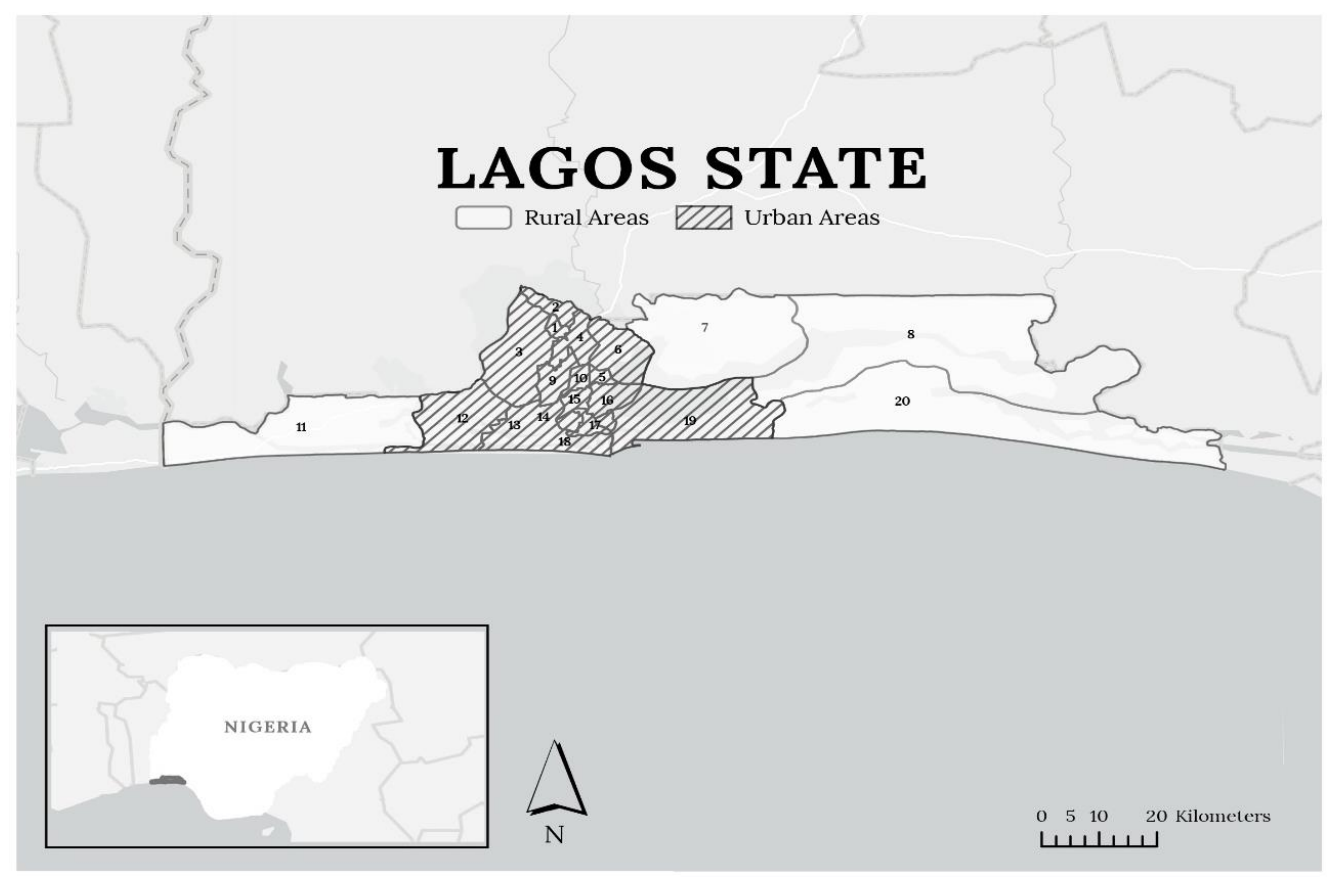

Figure 1. Map of Lagos State showing the 20 Local Government Areas with delineation of urban and rural areas. 
In the past few years, the Lagos region has witnessed a fast-growing population and urban development which has altered its landscape. The Lagos region metamorphosed from a less important agricultural community into its current megacity status [63].

However, the effect of population change as a driving force on land use has attracted much attention lately. Thus, deductions could be drawn about the impacts of population pressure after different types of comparative empirical work. But this empirical evidence is still lacking in developing countries [64]. In Nigeria for instance, it is known that the changing population-land affiliation and the related land use change have noticeable implications for the socio-economic conditions of the people and the environment [65].

\section{Data Description}

For this study, the description of the remotely sensed data used is illustrated in Table 2.

Table 2. Description of the collected remotely sensed data utilized in analyses.

\begin{tabular}{ccccc}
\hline Data Type & Dataset & Year & Resolution & Source \\
\hline Land use & GlobeLand30 & $2000 \& 2010$ & 30 m multispectral & National Geomatics Center of China (NGCC) \\
\hline
\end{tabular}

The GlobeLand30, which is a land cover dataset produced by the National Geomatics Center of China (NGCC), was utilized. This dataset has a $30 \mathrm{~m}$ high resolution imagery that covers the period from 2000 to 2010 [66]; they are produced based on over 10,000 data images obtained mainly from Landsat Thematic Mapper (TM) and Enhanced Thematic Mapper plus (ETM+). GlobeLand30 was a product of integration of a pixel-object knowledge-based method [67,68], and the Landsat images has minimal cloud cover and noiseless [69], which makes it appropriate for this study. A global accuracy of over $80 \%$ (i.e., $>80 \%$ ) were reported for the dataset [68,70,71]. As well, GlobeLand30 contain 10 land cover types [68], 8 (cultivated land, forest, grassland, shrubland, wetland, water bodies, artificial surfaces, and bareland) of which are applicable to Nigeria as itemized in Table 3.

Accuracy assessment of the dataset was conducted using high-resolution Google Earth images for study on land use land cover (LULC) change and statistical modeling of cultivated land change drivers in Nigeria [72]. The overall accuracy of $>73 \%$ in 2000 and $>75 \%$ in 2010 was achieved; thus, the suitability of this dataset for the analysis of this study was found to be high.

Table 3. GlobeLand30 land-cover types used for the study (Chen et al. [68]).

\begin{tabular}{|c|c|c|}
\hline Land Cover Code & Land Cover Type & Description \\
\hline 10 & Cultivated land & $\begin{array}{l}\text { Lands used for agriculture, horticulture and gardens, } \\
\text { including paddy fields, irrigated and dry farmland, vegetation } \\
\text { and fruit gardens, etc. }\end{array}$ \\
\hline 20 & Forest & $\begin{array}{l}\text { Lands covered with trees, with vegetation cover over } 30 \% \text {, } \\
\text { including deciduous and coniferous forests, and sparse } \\
\text { woodland with } 10 \%-30 \% \text { cover, etc. }\end{array}$ \\
\hline 30 & Grassland & $\begin{array}{l}\text { Lands covered by natural grass with a cover over } 10 \% \\
\text { including typical grassland, meadow grassland, alpine } \\
\text { grassland, desert grassland. }\end{array}$ \\
\hline 40 & Shrubland & $\begin{array}{l}\text { Lands covered with shrubs with a cover over } 30 \% \text { including } \\
\text { deciduous and evergreen shrubs and desert steppe with a } \\
\text { cover over } 10 \% \text {, etc. }\end{array}$ \\
\hline 50 & Wetland & $\begin{array}{l}\text { Lands covered with wetland plants and water bodies } \\
\text { including inland marsh, lake marsh, sea marsh, river } \\
\text { floodplain wetland, forest/shrub wetland, peat bogs, } \\
\text { mangrove and salt marsh, etc. }\end{array}$ \\
\hline 60 & Water bodies & $\begin{array}{l}\text { Water bodies in the land area, including rivers, lakes, } \\
\text { reservoirs, fish ponds, etc. }\end{array}$ \\
\hline
\end{tabular}


Table 3. Cont.

\begin{tabular}{ccl}
\hline Land Cover Code & Land Cover Type & \multicolumn{1}{c}{ Description } \\
\hline 70 & Tundra & $\begin{array}{l}\text { Lands covered by lichen, moss, hardy perennial herb, and } \\
\text { shrubs in the polar regions, including shrub tundra, } \\
\text { herbaceous tundra, wet tundra and barren tundra, etc. }\end{array}$ \\
\hline 80 & Artificial surfaces & $\begin{array}{l}\text { Lands modified by human activities, including all kinds of } \\
\text { habitations, industrial and mining area, transportation } \\
\text { facilities, and interior urban green zones and water bodies, etc. }\end{array}$ \\
\hline 100 & Bareland & $\begin{array}{l}\text { Lands with vegetation cover lower than 10\% including desert, } \\
\text { sandy fields, Gobi, bare rocks, saline and alkaline lands, etc. }\end{array}$ \\
\hline
\end{tabular}

\section{Methods}

This section explains the methods used for the land use change and impacts in urban and rural areas of Lagos State. Figure 2 illustrates the flowchart of the study, which consists of: (a) land use data-GlobeLand30 product; (b) creation of suitability maps of land use change using Esri ArcGIS 10.6; and (c) integration of a FRAGSTATS (Patch Analyst raster version) to compute the landscape-level and class-level metrics for each land cover type. This implies that the methods of this study were based on the evaluation of LULC changes and landscape metrics analysis.

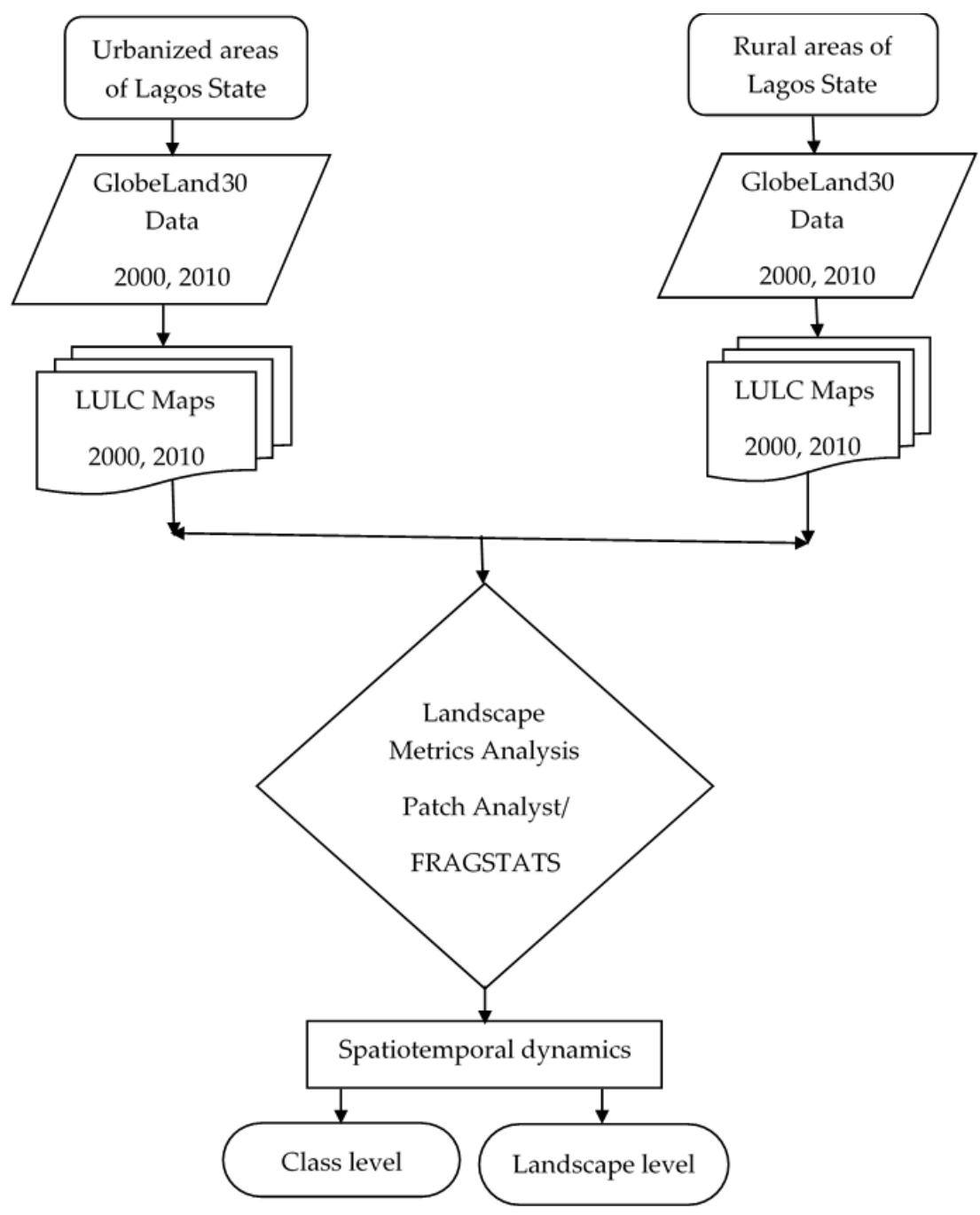

Figure 2. Flowchart of Methods. 


\subsection{LULC Maps Used}

In this study, the Esri ArcGIS 10.6 software was used to perform the analysis of the GlobeLand30 product of years 2000 and 2010 in Lagos State. The Universal Transverse Mercator (UTM) projection system within zone 31 North with a World Geodetic System (WGS) 1984 at $30 \mathrm{~m}$ spatial resolution was used as the reference system. Figure 3 shows the classified LULC maps of Lagos State used during the period of study.

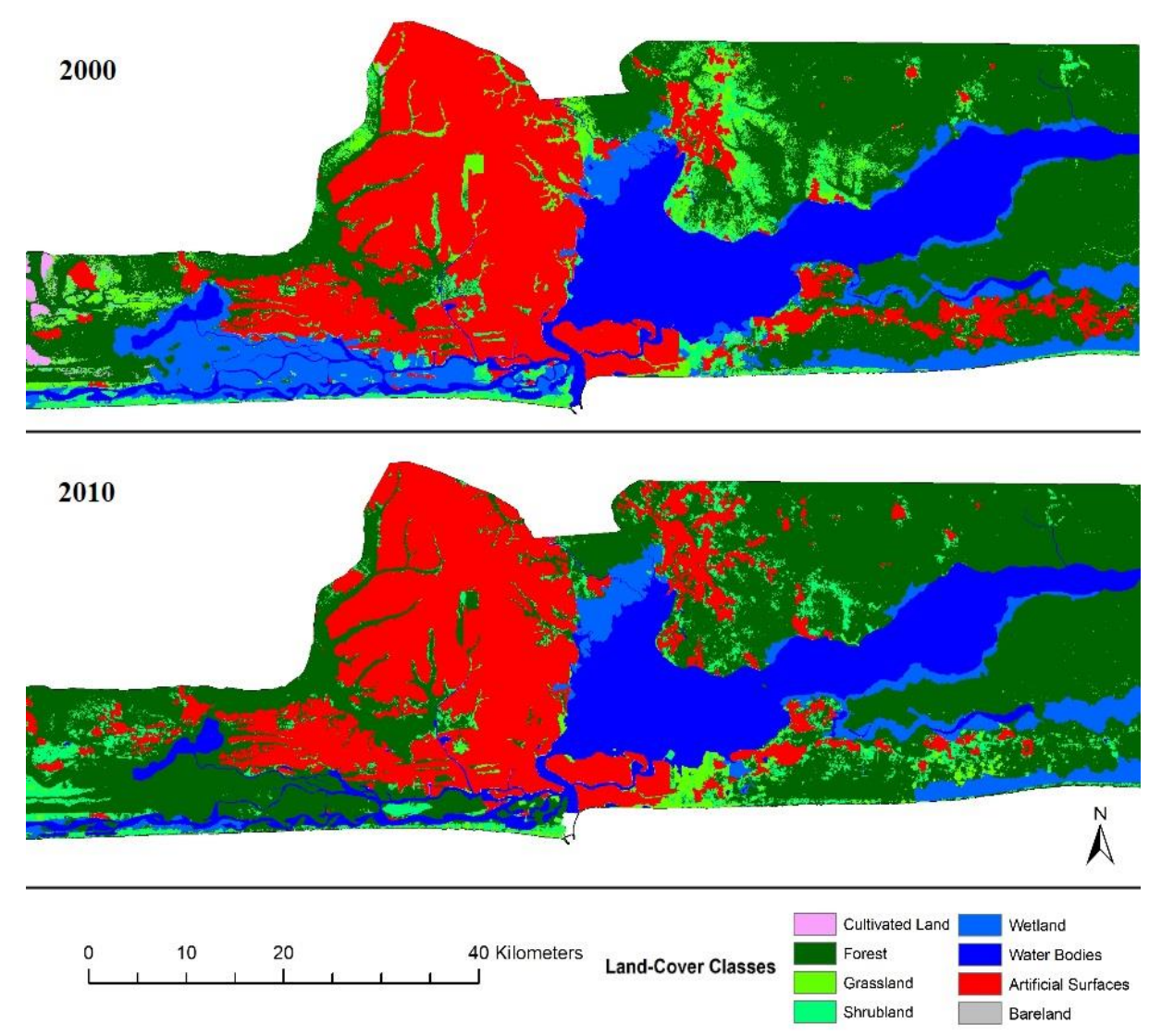

Figure 3. Classified land use and land cover (LULC) maps of Lagos State for years 2000 and 2010.

\subsection{Landscape Metrics Analysis}

Landscape metrics (LMs) are quantitative tools and environmental indicators used to define the structures and spatial pattern of a landscape $[48,73,74]$. They have been recognized to be appropriate for landscape analysis, although they are restricted because of up and downscaling of the generated results $[18,31,46,58,75]$. Since the 1990s, the introduction and advancement of landscape metrics has resulted in speedy progress of mapping landscape ecology [74].

Landscape metrics can be calculated on three different levels: patch, class, and landscape levels [76]. In this study, landscape-level and class-level metrics were employed. Class-level metrics are used to qualify the characteristics of the same LULC type and return a unique value for each class in the landscape [77]. Quite a lot of different metrics [73,78] were developed and improved based on the work of O'Neill et al. [48]. Thus, software was developed to update computation of landscape metrics [52], which helped to improve their use. In this study, LMs were calculated using the Patch Analyst which is an extension to the ArcGIS (ArcMap) 10.6 software. The Patch Analyst extension calculates spatial statistics on both polygon files (e.g., shape files) and raster files (e.g., Arc grids). Thus, landscape metrics at the landscape-level and class-level for individual land cover types were computed with the raster version of the Patch Analyst. In this case, the input data included GlobeLand30 LULC Maps of 2000 and 2010 (the generated maps were divided into categories-urban and rural) of Lagos State 
(see Figure 2), which were imported into ArcMap and converted into grid (raster) files for analysis in the FRAGSTATS situated in the Patch Analyst.

Moreover, the following 12 landscape metrics in the Patch Analyst extension program were included in the analysis: AWMSI (area weighted mean shape index), MSI (mean shape index), MPFD (mean patch fractal dimension), AWMPFD (area weighted mean patch fractal dimension), TE (total edge), ED (edge density), MPS (mean patch size), NUMP (number of patches), PSCOV (patch size coefficient of variance), PSSD (patch size standard deviation), CA (class area), and SDI (Shannon's diversity index). The descriptions of the landscape metrics that were used in this study are obtainable in the Patch Analyst User's Manual [79]. Also, the ecological denotations of these landscape metrics were detailed in Herold et al. $[27,80,81]$ (Visit this Website for information about the denotations of LMs: http://www.umass.edu/landeco/research/fragstats/documents/fragstats.help.4.2.pdf).

Table 4 shows the 12-landscape metrics adapted from the above-mentioned scholars. The table displays the names, acronyms, and units of measure of the metrics used.

Table 4. Landscape metrics used in the analysis.

\begin{tabular}{ccc}
\hline Metrics & Acronym & Unit \\
\hline Area Weighted Mean Patch Fractal Dimension & AWMPFD & none \\
Area Weighted Mean Shape Index & AWMSI & none \\
Class Area & CA & ha \\
Edge Density & ED & m/ha \\
Mean Patch Fractal Dimension & MPFD & none \\
Mean Patch Size & MPS & ha \\
Mean Shape Index & MSI & none \\
Number of Patches & NUMP & none \\
Patch Size Coefficient of Variance & PSCOV & none \\
Patch Size Standard Deviation & PSSD & ha \\
Shannon's Diversity Index & SDI & information \\
Total Edge & TE & m \\
\hline
\end{tabular}

The Shannon's diversity index, which is only available at the landscape level, is a relative measure of patch diversity. The SDI is equal to zero when there is only one patch in the landscape, and it increases as the number of patch types increases [73]. In this study, SDI was used to analyze the richness of the diversity of different land use types within the administrative boundaries of Lagos State LGAs. Finally, the selection and combination of numerous metrics for this study corroborate the suggestions mentioned by scholars indicating that a mixture of several indices allow a better understanding of the fragmentation process [74]. After the computation of the landscape fragmentation indices for all the classified LULC maps using FRAGSTATS, research results are shown in Tables 5-7.

Table 5. Overall landscape metrics for Lagos State Urban and Rural areas in 2000 and 2010.

\begin{tabular}{|c|c|c|c|c|c|c|c|c|c|c|c|}
\hline Year & AWMSI & MSI & MPFD & AWMPFD & TE & ED & MPS & NUMP & PSCOV & PSSD & $\mathrm{CA}$ \\
\hline \multicolumn{12}{|c|}{ Urban Areas } \\
\hline 2000 & 7.18 & 1.32 & 1.04 & 1.2 & $4,780,620$ & 37.72 & 11.77 & 10,764 & 4104.58 & 483.25 & 0 \\
\hline 2010 & 7.57 & 1.37 & 1.05 & 1.21 & $4,047,480$ & 31.99 & 20.2 & 6264 & 3138.66 & 633.91 & 0 \\
\hline \multicolumn{12}{|c|}{ Rural Areas } \\
\hline 2000 & 12.87 & 1.3 & 1.04 & 1.25 & $13,699,500$ & 54.49 & 7.78 & 32,302 & 5488.93 & 427.21 & 0 \\
\hline 2010 & 9.04 & 1.33 & 1.04 & 1.22 & $6,654,720$ & 26.47 & 27.08 & 9284 & 3376.75 & 914.29 & 0 \\
\hline
\end{tabular}


Table 6. Class-specific landscape metrics for Lagos State Urban and Rural areas in 2000 and 2010.

\begin{tabular}{|c|c|c|c|c|c|c|c|c|c|c|c|}
\hline $\begin{array}{c}\text { Land Cover } \\
\text { Types }\end{array}$ & AWMSI & MSI & MPFD & AWMPFD & TE & ED & MPS & NUMP & PSCOV & PSSD & CA \\
\hline \multicolumn{12}{|c|}{ Urban Areas } \\
\hline Cultivated land & 2.02 & 1.34 & 1.05 & 1.13 & 216,480 & 1.71 & 0.43 & 624 & 357.21 & 1.54 & 268.74 \\
\hline Forest & 10.04 & 1.34 & 1.04 & 1.25 & $1,927,680$ & 15.21 & 9.26 & 1758 & 2216.61 & 205.35 & $16,286.04$ \\
\hline Grassland & 4.19 & 1.33 & 1.05 & 1.19 & $1,724,880$ & 13.61 & 1.84 & 2733 & 779.34 & 14.37 & 5040.9 \\
\hline Water bodies & 9.13 & 2 & 1.08 & 1.23 & 688,320 & 5.43 & 976.3 & 29 & 523.14 & 5107.4 & $28,312.56$ \\
\hline Artificial surfaces & 6.96 & 2.19 & 1.09 & 1.2 & $1,263,480$ & 9.97 & 1356.75 & 41 & 454.49 & 6166.27 & $55,626.75$ \\
\hline \multicolumn{12}{|c|}{2010} \\
\hline Cultivated land & 1.57 & 1.22 & 1.04 & 1.09 & 115,080 & 0.91 & 0.27 & 448 & 111.85 & 0.3 & 120.51 \\
\hline Forest & 8.81 & 1.42 & 1.06 & 1.22 & $2,779,860$ & 21.97 & 17.63 & 1765 & 1741.65 & 307.05 & $31,116.42$ \\
\hline Artificial surfaces & 7.12 & 2.16 & 1.09 & 1.2 & $1,297,260$ & 10.25 & 1259.87 & 44 & 469.74 & 5918.18 & $55,434.42$ \\
\hline \multicolumn{12}{|c|}{ Rural areas } \\
\hline \multicolumn{12}{|c|}{2000} \\
\hline Cultivated land & 3.49 & 1.6 & 1.07 & 1.15 & 417,540 & 1.66 & 34.21 & 129 & 355.39 & 121.57 & 4412.7 \\
\hline Forest & 18.35 & 1.29 & 1.04 & 1.29 & $8,862,600$ & 35.25 & 25.57 & 5177 & 3469.99 & 887.24 & $132,369.66$ \\
\hline Grassland & 10.71 & 1.32 & 1.04 & 1.26 & $7,835,160$ & 31.16 & 2.38 & 10321 & 2181.82 & 51.98 & $24,589.98$ \\
\hline Shrubland & 8.2 & 1.27 & 1.04 & 1.24 & $5,787,660$ & 23.02 & 0.86 & 12116 & 1450.99 & 12.54 & $10,467.99$ \\
\hline Wetland & 5.42 & 2.5 & 1.12 & 1.18 & 965,940 & 3.84 & 414.12 & 54 & 370.36 & 1533.76 & $22,362.75$ \\
\hline Water bodies & 5.87 & 2.08 & 1.1 & 1.18 & 777,180 & 3.09 & 1447.73 & 32 & 484.01 & 7007.09 & $46,327.32$ \\
\hline Artificial surfaces & 4.93 & 1.81 & 1.08 & 1.17 & 627,120 & 2.49 & 90.24 & 96 & 382.17 & 344.86 & 8662.68 \\
\hline
\end{tabular}

Table 7. Variation in Shannon's Diversity Index between 2000 and 2010 in Lagos State.

\begin{tabular}{ccccc}
\hline Local Government Area & Urban/Rural & $\mathbf{2 0 0 0}$ & $\mathbf{2 0 1 0}$ & Variation in SDI \\
\hline Agege & Urban & 0.09 & 0.14 & 0.05 \\
Ajeromi-Ifelodun & Urban & 0.52 & 0.60 & 0.08 \\
Alimosho & Urban & 0.82 & 0.62 & -0.20 \\
Amuwo-Odofin & Urban & 1.64 & 1.29 & -0.35 \\
Apapa & Urban & 1.32 & 1.28 & -0.04 \\
Badagry & Rural & 1.59 & 1.17 & -0.42 \\
Epe & Rural & 1.13 & 0.82 & -0.31 \\
Eti-Osa & Urban & 1.70 & 1.70 & 0.00 \\
Ibeju-Lekki & Rural & 1.43 & 1.16 & -0.27 \\
Ifako-Ijaiye & Urban & 0.22 & 0.25 & 0.03 \\
Ikeja & Urban & 0.39 & 0.44 & 0.05 \\
Ikorodu & Rural & 1.13 & 0.93 & -0.20 \\
Kosofe & Urban & 1.48 & 1.28 & -0.20 \\
Lagos Island & Urban & 0.72 & 0.75 & 0.03 \\
Lagos Mainland & Urban & 0.39 & 0.41 & 0.02 \\
Mushin & Urban & 0.05 & 0.05 & 0.00 \\
Ojo & Urban & 1.49 & 1.12 & -0.37 \\
Oshodi-Isolo & Urban & 0.56 & 0.49 & -0.07 \\
Shomolu & Urban & 0.47 & 0.48 & 0.01 \\
Surulere & Urban & 0.38 & 0.39 & 0.01 \\
\hline
\end{tabular}




\section{Results and Discussions}

The GlobeLand30 datasets of 2000 and 2010 for the urban and rural areas of Lagos State are shown in Figure 4. From these, change maps from 2000 and 2010 were produced.

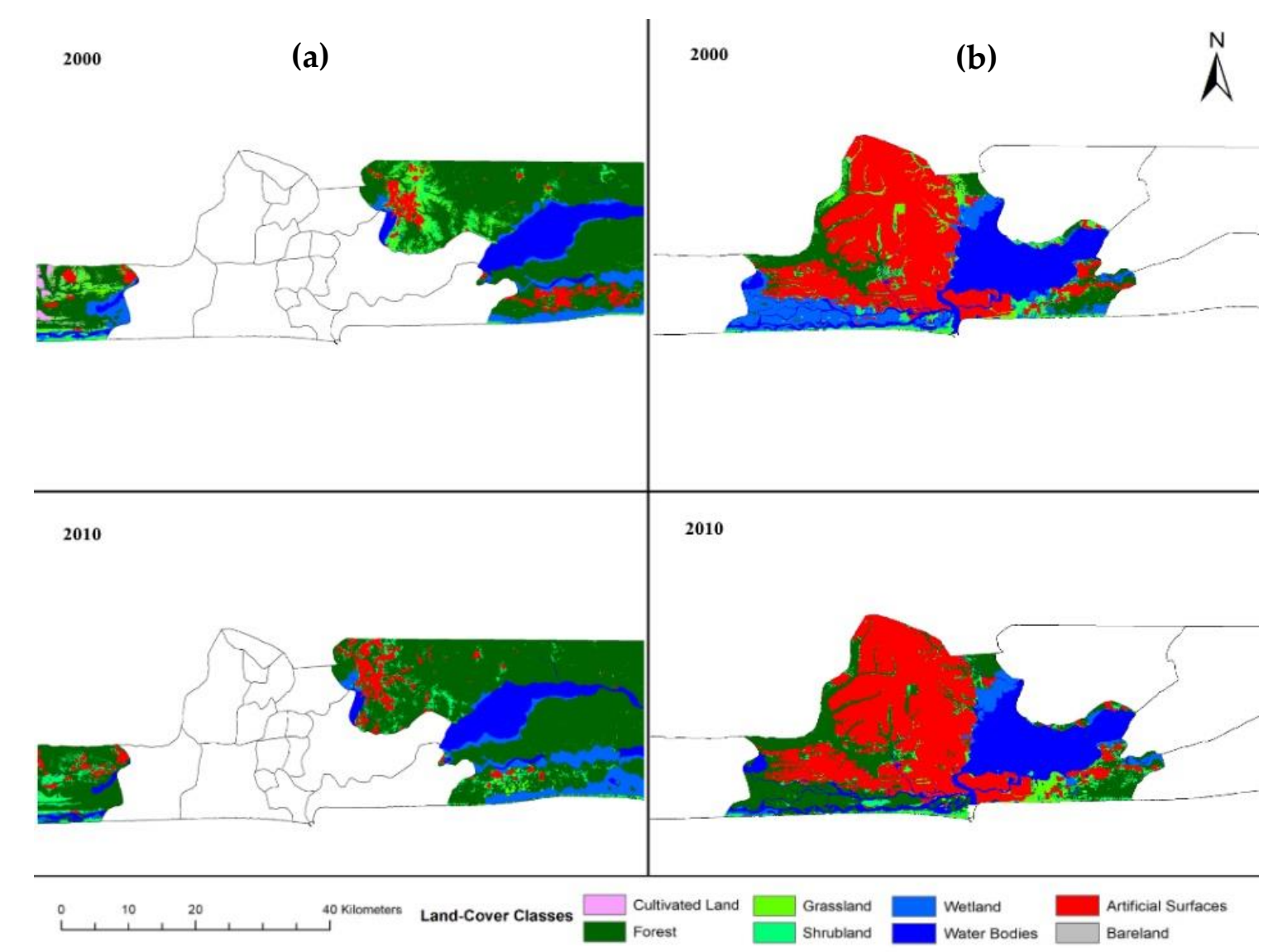

Figure 4. Land cover change maps for (a) rural and (b) urban areas of Lagos State from 2000 to 2010.

Thus, the following analysis focuses on the spatiotemporal dynamics of land use change and impacts on urban and rural areas of study.

\subsection{Patch Analysis: Overall Landscape Metrics and Class-Specific Landscape Metrics for Urban Areas in} Lagos State

The FRAGSTATS generated statistical results for urban areas of Lagos State are explained subsequently. The overall landscape fragmentation for Lagos State urban areas display slight increases for AWMSI, MSI, MPFD, AWMPFD, and MPS, while the PSSD showed a substantial increase from 2000 to 2010 (Table 5). Also, TE, ED, NUMP, and PSCOV decreased during the period of study. Total Edge exhibited the highest decrease, next is the NUMP while ED slightly decreased, and CA generated zero numbers during the time of study (Table 5). The zero numbers of CA denote that the patch types became increasing scarce in the Lagos State landscape between 2000 and 2010.

The land-cover class data for urban areas of Lagos State in 2000 and 2010 is presented in Table 6. During the time of study, the landscape of each land cover type showed different trends of change. It is important to mention that the FRAGSTATS statistical results for class-specific landscape metrics generated numbers for bareland in year 2000, but not any numbers were generated for this land cover type in 2010. As a result, bareland was not itemized in the class-specific landscape metric Table 6 for discussion. Firstly, the AWMSI metric for grassland and artificial surfaces displayed increments with grassland presented a higher increment amount of 1.88 than artificial surfaces of 0.16 from 2000 to 
2010. Also, there were declines in cultivated land, forest, shrubland, wetland, and waterbodies during the period of study. The most noticeable decline occurred with forest with an amount of 1.23, and wetland showed the lowest decline amount of 0.20. In conclusion, the AWMSI of cultivated land, forest, shrubland, wetland, and waterbodies showed that shape irregularity in 2000 had decreased in 2010. Besides, the increase in artificial surfaces for AWMSI metric could suggest an urban sprawl that possibly was not well-planned in Lagos State.

The MSI of forest, shrubland and wetland increases in the urban areas; wetland showed the highest increase at the rate of 0.19 , and shrubland displayed the lowest increase amount of 0.04 from 2000 to 2010. In addition, cultivated land, grassland, waterbodies, and artificial surfaces showed reductions in urban areas of Lagos State. The greatest reduction of 0.23 was displayed by waterbodies, while artificial surfaces showed the lowest reduction with the sum of 0.03 .

The MPFD of forest and wetland increases in the urban areas of Lagos State during the period of study. It is worth mentioning that both forest and wetland exhibited the same increment of 0.02 from 2000 to 2010. Moreover, cultivated land, grassland, and waterbodies decreases during the study period, and the rate of decreases, i.e., 0.01 are the same for these three land cover types. Furthermore, shrubland and artificial surfaces presented no variations, thus, their amounts remain unchanged from 2000 to 2010. The MSI and MPFD metrics quantify the complexity of a patch shape [80]. As shown in Table 6, both metrics show a similar trend in change, and the values of both show growing trends for forest and wetland as well as decreasing trends for cultivated land, grassland, and waterbodies. The shape index signifies the regularity of a land cover type; a higher value represents higher irregularity while a decrease value implies a more regular shape of the patch. Results of this study in urban areas of Lagos State suggest that the shape of the forest and wetland became more irregular, but the shapes of the cultivated land, grassland, and waterbodies changed into more compact and regular shapes.

The AWMPFD metric for grassland increased marginally from 1.19 in 2000 to 1.20 in 2010 in Lagos State urban areas. Also, cultivated land, forest, shrubland, and waterbodies showed slight decreases; the greatest decrease of 0.04 was recorded for cultivated land and waterbodies exhibited the smallest reduction of the sum of 0.01 during the study period. As well, wetland and artificial surfaces presented no variations, thus, their amounts were unchanged from 2000 to 2010. The AWMPFD can be used to calculate the complexity of patch shape at a given observation scale. The lower value of AWMPFD lead to a more regular patch shape in the landscape and greater human disturbance on the patches. Finally, the decreases recorded for cultivated land, forest, shrubland, and waterbodies imply an increment of the intensity of human activities on these land cover types in urban areas of Lagos State; while the slight increase of AWMPFD for grassland meant the lessening of human disturbances on grassland in the study area.

Total edge (TE) equals the sum of the lengths $(\mathrm{m})$ of all edge segments involving the corresponding patch type. It is an absolute measure of total edge length of a patch type (class level) or of all patch types (landscape level) [81]. The TE of forest and artificial surfaces increased in the urban areas for the period of 10 years studied. Forest exhibited a higher increase of $852,180 \mathrm{~m}$ in contrast to an increment from artificial surfaces. Also, the TE of cultivated land, grassland, shrubland, wetland and waterbodies declined; the TE of grassland exhibited the highest decrease amount of 1,031,040 $\mathrm{m}$ while waterbodies exhibited the least decrease amount of 17,940 m from 2000 to 2010, respectively.

Edge density equals the sum of the lengths $(\mathrm{m})$ of all edge segments in the landscape, divided by the total land area (TLA) $\left(\mathrm{m}^{2}\right)$, multiplied by 10,000 (to convert to hectares) [81]. From 2000 to 2010, the ED of forest and artificial surfaces increased in Lagos State urban areas with forest showing the higher increase of $6.76 \mathrm{~m} / \mathrm{ha}$ against $0.28 \mathrm{~m} / \mathrm{ha}$ for artificial surfaces. For the period of study, the ED of cultivated land, grassland, shrubland, wetland, and waterbodies decreased in the urban areas. Grassland presented the highest decrease of $8.13 \mathrm{~m} / \mathrm{ha}$, while waterbodies showed the lowest decrease of $0.13 \mathrm{~m} /$ ha from 2000 to 2010 .

Mean patch size (MPS) is the amount of central tendency in the patch characteristics of the entire landscape [81]. In this study, the MPS metric shows that forest, grassland, shrubland, and wetland 
in urban areas displayed increased amounts between 2000 and 2010. Wetland showed the highest increase of 15.92 ha and shrubland displayed the lowest increase of 0.21 ha. Moreover, the MPS metric for cultivated land, waterbodies, and artificial surfaces diminished; water bodies displayed the greatest decrease with the sum of 390.28 ha, and cultivated land showed the lowest decrease with the sum of 0.16 ha from 2000 to 2010. The fragmentation of cultivated land can be observed by the decrease of MPS. Thus, in this study, the reduction of MPS of cultivated land implies that cultivated lands had become more fragmented because of the loss of agricultural land.

Number of patches (NUMP) is an important metric which measures the degree of division or fragmentation of a specific patch type. The subdivision deals with the rate to which patch types are broken up into distinct patches [80]. The NUMP of forest, water bodies, and artificial surfaces increased in the urban areas; the highest metric increase of 18 occurred to water bodies while the lowest increase amount of 3 was displayed by artificial surfaces from 2000 to 2010. Between the period of 2000 and 2010, the NUMP of cultivated land, grassland, shrubland, and wetland displayed decreasing amounts in urban areas with the greatest decrease occurring to grassland at the rate of 1643, and the lowest decrease at the rate of 47 was shown by wetland. This decrease in patches indicate a lesser number of disturbances to the cultivated landscape in Lagos State during this ten-year duration. This reduction of the size of cultivated land patches substantiates the views of scholars that cultivated lands show a process of reduction in size to lesser exploitations [82].

Regarding discussion on the NUMP, MPS, and ED metrics for cultivated land in urban areas; decreases in values of NUMP, MPS and ED metrics for cultivated land indicate that cultivated land decreased in amounts, size, and edge in urban areas of Lagos State (see the urban segment of Table 6).

As itemized in Table 6, the PSCOV of grassland, waterbodies, and artificial surfaces showed increments in the Lagos State urban areas between 2000 and 2010. Grassland showed the highest increase of 747.21, while artificial surfaces displayed the lowest increase of 15.25. Results of spatial analysis also showed declines for cultivated land, forest, shrubland, and wetland. The highest decrease with the sum of 474.96 was recorded for forest, and wetland showed the lowest decrease with an amount of 26.25 .

The PSSD of forest and grassland increased in the urban areas, and the higher increase was documented for forest at the quantity of 101.70 ha. In addition, the PSSD of cultivated land, shrubland, wetland, waterbodies, and artificial surfaces reduces during the study period in the urban areas of Lagos State. The greatest reduction with the sum of 1197.93 ha occurred with waterbodies, while cultivated land presented the lowest reduction with the quantity of 1.24 ha.

The CA of forest increased in the urban areas from 16,286.04 ha in 2000 to 31,116.42 ha in 2010. The CA of other land cover types-cultivated land, grassland, shrubland, wetland, waterbodies, and artificial surfaces showed declines in urban areas during the period of this study, but the highest decrease among these six land-cover types occurred with wetland at the amount of 10,458.81 ha while cultivated land showed the lowest decrease with the sum of 148.23 ha from the 2000 to 2010 study period.

Subsequently, cultivated land and artificial surfaces classes presented some differences. Results of spatial analysis of the landscape metrics (except MSI, MPS, PSSD, and CA) showed decreases in cultivated lands and increments in artificial surfaces in the urban LGAs of Lagos State between 2000 and 2010 (see Table 6). Thus, the growth of artificial surfaces was responsible for cultivated land decline. In 2010, the NUMP of cultivated lands had less intensive fragmentation than in 2000. The consistent decline in other fragmentation metrics, such as AWMSI, MSI, MPFD, AWMPFD, TE, ED, MPS, PSCOV, PSSD, and CA suggests that cultivated landscapes in 2010 were less fragmented. During the period of study, the NUMP of forest, water bodies, and artificial surfaces increased in the urban areas of Lagos State. Also, the NUMP of grassland, shrubland, and wetland decreased in urban areas (see Table 6). Relating the declines in cultivated lands to the increment in forest, it can be deduced that the lost cultivated land was being replaced by forest, which was due to the 2008 urban renewal and tree planting program carried out by the Lagos State government. This program was envisioned to help 
in alleviation of the harmful effects of climate change, thereby promoting a greener, healthier, and sustainable environment [83].

\subsection{Patch Analysis: Overall Landscape Metrics and Land-Cover Class Level for Rural Areas in Lagos State}

The spatiotemporal dynamics of landscapes for Lagos State rural areas were contrasted from the urban areas. The degree of landscape fragmentation in rural areas increased for the MSI, MPS, and PSSD metrics (Table 5). AWMSI, AWMPFD, TE, ED, NUMP, and PSCOV exhibited declines from 2000 to 2010. Substantial decreases were presented for TE and NUMP, while the AWMPFD metric showed a slight decrease. Besides, the overall land scape metric for CA in rural areas generated zero figures alongside urban areas during the time of study. Although AWMSI seemed to decrease, the extent of this decrease was higher than for MSI (Table 5), implying that larger patches have more complex shapes; the increment of MSI portrayed the increased irregularity in patch shapes.

Results of the FRAGSTATS statistical analysis for rural areas of Lagos State (see Table 6) showed that the AWMSI metric for all the land-cover types (cultivated land, forest, grassland, shrubland, wetland, water bodies, and artificial surfaces) decreased between 2000 and 2010. Grassland exhibited the highest decrease with the quantity of 8.01 , and water bodies recorded the lowest decrease with the quantity of 0.10 .

The MSI metrics for forest, shrubland, and artificial surfaces presented increments in the rural areas of Lagos State during the period of this study. Artificial surfaces displayed the highest increment of the sum of 0.21 while forest showed the lowest increment of the sum of 0.02 from 2000 to 2010 . The MSI of cultivated land, grassland, wetland, and water bodies showed decreases; cultivated land displayed the greatest decrease with an amount of 0.42 , while grassland exhibited the lowest decrease with an amount of 0.05 .

Results showed that the MPFD metric for artificial surfaces increased from 1.08 in 2000 to 1.10 in 2010. Also, the MPFD of cultivated land and water bodies exhibited slight declines; the greater decrease occurred from cultivated land with an amount of 0.04 . It is worth mentioning that the quantities of MPFD metric for forest, grassland, shrubland, and wetland were unchanged from 2000 to 2010 (see Table 6). For example, the metric of forest, grassland, and shrubland generated the same amount, i.e., 1.04 in 2000 and remained the same at 1.04 in 2010. Also, the amount of wetland was 1.12 in 2000, and it was unchanged and remained at 1.12 in 2010 (see Table 6).

The AWMPFD of cultivated land, forest, grassland, shrubland, and artificial surfaces decreased in the rural areas of Lagos State from 2000 to 2010. Grassland showed the greatest decrease with the quantity of 0.12 , and both shrubland and artificial surfaces displayed the lowest decrease with the quantity of 0.01 between 2000 and 2010, respectively. The AWMPFD of wetland and water bodies generated the same quantity of 1.18 in 2000 and remained at 1.18 in 2010 apiece without changing (Table 6).

The TE of water bodies and artificial surfaces in rural areas of Lagos State showed increments for the period of 10 years studied. Artificial surfaces recorded the larger increment with the sum of $142,380 \mathrm{~m}$. Also, the TE of cultivated land, forest, grassland, shrubland, and wetland decreases during the study period. The TE of grassland exhibited the highest decrease with the sum of 7,140,660 $\mathrm{m}$ and wetland presented the lowest decrease with the sum of 154,560 m from 2000 to 2010.

From 2000 to 2010, the ED of water bodies and artificial surfaces in rural areas of Lagos State showed increases. Artificial surfaces recorded the larger increase with the sum of $0.57 \mathrm{~m} / \mathrm{ha}$. Moreover, the TE of cultivated land, forest, grassland, shrubland, and wetland reduced during the study period. The TE of grassland exhibited the highest reduction with the sum of $28.40 \mathrm{~m} / \mathrm{ha}$ and wetland presented the lowest reduction with an amount of $0.61 \mathrm{~m} /$ ha between 2000 and 2010.

The MPS of forest, shrubland, and artificial surfaces increased in the Lagos State rural areas between 2000 and 2010. Forest showed the greatest increase with the quantity of 48.92 ha while shrubland displayed the lowest increase with a quantity of 2.08 ha. Thus, the increment of MPS for artificial surfaces could imply there was rapid economic development, which resulted to an increasing 
demand for land use for construction and housing with consequent loss of agricultural land in rural areas of Lagos State. Also, cultivated land, grassland, wetland, and waterbodies showed decreases; the greatest decrease occurred with waterbodies with the sum of 538.26 ha, and grassland exhibited the lowest decrease with the sum of 0.93 ha in the rural areas during the study period.

Moreover, the NUMP of cultivated land, waterbodies, and artificial surfaces increased from 2000 to 2010. The greatest increase was documented for cultivated land with the sum of 72 while artificial surfaces demonstrated the lowest increase by a sum of 8 during the period of study. Also, the amounts of NUMP for forest, grassland, shrubland, and wetland showed reductions. Grassland presented the greatest reduction with a quantity of 8951, while wetland showed the lowest reduction of 6 between 2000 and 2010 in the rural areas.

The PSCOV of cultivated land, shrubland, wetland, and water bodies presented increments in the rural areas between 2000 and 2010 study period. The highest increment was recorded for water bodies with the amount of 120.37 and the lowest increment amount of 0.97 was documented for wetland. Besides, the PSCOV of forest, grassland, and artificial surfaces reduced; grassland showed the greatest reduction at the rate of 1648.99 while artificial surfaces displayed the lowest reduction at the rate of 21.41 in the Lagos State rural areas.

The PSSD of forest and shrubland rises in the rural areas during the period of study with the higher rise of 802.76 ha displayed by the forest. However, the PSSD of cultivated land, grassland, wetland, water bodies, and artificial surfaces decreased. The metric for water bodies displayed the greatest decrease at the rate of 1510.44 ha, while artificial surfaces exhibited the lowest decrease at the rate of 10.05 ha between 2000 and 2010.

Lastly, the CA of forest, shrubland, and artificial surfaces increased in the rural areas, and the greatest increase was displayed by forest at the rate of 25,696.89 ha while artificial surfaces showed the lowest increase at the rate of 989.37 ha between 2000 and 2010. But, the CA of cultivated land, grassland, wetland, and water bodies all showed reductions, and the greatest reduction was presented by grassland at the quantity of $22,600.62$ ha while water bodies showed the lowest reduction at the quantity of 854.01 ha during the period of the study.

It is worth mentioning that the increasing fragmentation of cultivated lands in the rural areas of Lagos State may be attributed to rising anthropogenic incursion into cultivated landscapes that occurred as the outcome of urban expansion. The NUMP of artificial surfaces in the rural areas presented an increase from 96 in 2000 to 104 in 2010 (see rural segment of Table 6), and this concurs with the possibility that urban sprawl from Lagos Metropolitan Region or expansion of artificial surfaces in the rural parts of Lagos State might have resulted in an increase in cultivated lands fragmentation. These research findings correspond with Dekolo et al.'s [43] study in Ikorodu municipality, which found a significant reduction in agricultural lands due to rapid urban changes. Moreover, the NUMP of forest, grassland, shrubland, and wetland (except water bodies) decreased in the rural areas of Lagos State during the study period. Concerning the land-cover types (forest, grassland, shrubland, and wetland) and their relationships with the landscape metrics in rural areas, the grassland showed declines in all the metrics, while CA recorded the greatest and most substantial decline. Similarly, wetland diminished for almost all the metrics except for PSCOV. However, forest decreased for most metrics with increments in MSI, MPS, PSSD, and CA (see rural segment of Table 6).

\subsection{Change of Landscape Diversity in Lagos State}

Shannon's diversity index is extensively used to detect the change of landscape diversity. A higher value of SDI signifies more landscape elements or more diverse landscape patterns. Table 7 below illustrates the variation in SDI between 2000 and 2010 in Lagos State. During the period of this study, the richness of the extant patches at the local government level enables us to comprehend whether significant changes occur in the land use and land cover. Thus, the SDI calculation made it possible to evaluate the richness of the diversity of the total land cover types for each LGA. 
As depicted in Table 7, findings from the Patch Analyst Software-FRAGSTATS concerning this landscape analysis showed a predominant decrease in diversity in ten LGAs, an increase in diversity occurring in eight LGAs, and there was no change in diversity in two LGAs throughout the years. Also, all the rural LGAs (Badagry, Epe, Ibeju-Lekki, and Ikorodu) mostly exhibited a decline in the diversity of patches-A negative SDI, while the more urbanized areas of Lagos (e.g., Agege, Ajeromi-Ifelodun, Ifako-Ijaiye, Ikeja, Lagos Island, Lagos Mainland, Shomolu, and Surulere) showed more change in the SDI.

Results substantiate Vaz et al.'s [12] study that applied SDI to quantify changes in agricultural areas in Algarve region, Portugal; the study found a lower SDI in rural areas while the urban areas reported a larger SDI. Thus, the diverse urban region of Lagos State could be associated with significant LULC changes. It is noteworthy that SDI variation for Eti-Osa and Mushin urban LGAs were equal to zero because no changes in landscape diversity were recorded in these two areas from 2000 to 2010. Finally, from the spatial concept, the findings demonstrate a signal of the loss of definite cultivated land cover types in the study area.

In summary, the major differences in spatiotemporal dynamics in urban and rural areas of Lagos State were: (a) overall, landscape fragmentation decreased in both areas, nevertheless, the decrease was larger in the rural areas. Cultivated land for all the metrics decreased in both areas but the proportion of the decrease was larger in the urban areas. Studies display a general trend of decreases in agricultural land during urbanization in several regions around the world [34-39]. Similarly, the rising agricultural land loss could have resulted from the constant propensity to use this land for urban activities, and may have been caused by the uncommonly rapid dynamics in the agricultural sector [12]; (b) fragmentation of artificial surfaces increased in both areas but the increment was higher in rural areas; (c) fragmentation of grassland, shrubland, and wetland reduces in both areas, but reductions of grassland and shrubland were larger in rural areas, and the reduction of wetland was larger in urban areas; (d) in comparison, fragmentation of cultivated land increased in the rural areas, but decreased in the urban areas; (e) fragmentation of forest showed an increase in the urban areas and a reduction in the rural areas; (f) in the urban areas, the fragmentation measure of diversity increased, in contrast to a decline in the rural areas.

\section{Conclusions}

Land use patterns are quickly changing within the urban and surrounding area of African cities [84]. Also, LULC is widely known as a local environmental issue worldwide [85]. Landscape metrics (LMs) have mainly been utilized in landscape ecology [12]; and they are effective instrument in LULC change detection and other environmental research [86]. Much work has been accomplished using landscape metrics and remote sensing; however, little research has been concentrated on land use change and impacts on urban and rural activity in Lagos State using these tools. This study was carried out to characterize landscape pattern changes and to quantify the impacts of land use changes in urban and rural areas of Lagos State using landscape metrics. The input data included GlobeLand30 dataset of 2000 and 2010 for Lagos State which were imported into ArcMap 10.6 and converted to grid (raster) files for statistical analysis in the FRAGSTATS algorithm situated in the Patch Analyst Software. Thus, landscape metrics at the landscape level and class-level for individual land cover types were computed with the raster version of the Patch Analyst to generate statistical results. The study of landscape metrics indicated loss of cultivated lands and changes in fragmentation between 2000 and 2010 in Lagos State. Firstly, it was found that fragmentation in cultivated lands in the rural areas increases during the time of study with the growth of urban region and diversification of land uses. Findings concur with the study which found that land use changes occur at the periphery of big city concentration where urbanization and industrialization pressures often result in loss of major agricultural lands and tree cover [87].

Next, land-use diversification leads to larger fragmentation of forest apart from near cultivated lands. Findings about increment in cultivated land fragmentation in rural areas, resulting from 
other land-use activities in urban region could lead to more deterioration of agricultural activities in Lagos State. Fragmentation that occurs through the conversion of agricultural lands to residential or manufacturing land uses may also have negative effects on the wildlife and on sustainable ecosystems $[88,89]$. The spatial variability of rural landscape attributes and pattern changes necessitate the development of land use management policies at the local, state, or federal levels [90]. In rural areas (such as Badagry, Epe, Ibeju-Lekki, and Ikorodu) around metropolitan region of Lagos State, environmental policy should focus on the enhancement of land use sustainability. However, the management of urbanized land requires decentralization of urban patches/urban land-use planning. Decentralization of urban patches specifies that urban areas such as Lagos metropolis with large physical size and high population density should reduce their growth cycles and enable peri-urban centers to grow. These growing peri-urban centers are characterized by lower levels of ecological footprints [91]. Because increasing the number of patches is an indication of ecosystem degradation [92], this strategy of decentralization of urban patches is a way of reducing the number of patches and addressing ecological problems on a regional scale.

This research has shown that LMs can be used to understand the spatial pattern of LULC change in an urban-rural context $[11,93,94]$. Moreover, the combination of GIS and LMs methods at the regional level with the spatiotemporal and statistical analysis can help to solve the problems of loss of agricultural lands and loss of the natural resource areas [12]. Also, the application of LMs to analyze landscape pattern changes reveal functional changes in the landscape, especially in a rapidly developing region [95]. Furthermore, LMs are universal, potent, and consistent; this suggests that landscape structures in different regions (e.g., Lagos State, Nigeria) have similar attributes including size, area similarity, and fragmentation, which can be studied by similar set of the metrics [77]. As well, these analytical tools may help decision makers to design more appropriate actions for land use management and sustainable environment. In conclusion, there is a need to adapt to the environmental policies and programs at the federal, state, and local levels to ensure the conservation and proper use of the Lagos State landscape.

Author Contributions: The authors directly contributed to the investigation throughout the duration of the research. O.O.O. applied the methodology, conducted the analysis, wrote the literature review, edited, and compiled the manuscript. E.V. reviewed, edited, and provided useful information for the preparation and submission of the manuscript. In addition, all authors have read and agreed to the published version of the manuscript.

Funding: This research received no external funding.

Acknowledgments: The lead author would like to thank Eric Vaz for his guidance, input, and supervision in all the phases of the study. The authors express gratitude to the reviewers and the Scientific Editor for their valuable comments.

Conflicts of Interest: The authors declare no conflict of interest.

\section{References}

1. Salvati, L.; Zambon, I.; Chelli, F.M.; Serra, P. Do spatial patterns of urbanization and land consumption reflect different socioeconomic contexts in Europe? Sci. Total Environ. 2018, 625, 722-730. [CrossRef] [PubMed]

2. Dadashpoor, H.; Alidadi, M. Towards decentralization: Spatial changes of employment and population in Tehran metropolitan region, Iran. Appl. Geogr. 2017, 85, 51-61. [CrossRef]

3. Dadashpoor, H.; Jahanzad, N.; Jalili, H. Analysis and forecasting of the integrated spatial structure in Mashhad metropolitan region in the period 1996-2041. J. Urban Stud. 2016, 5, 51-62.

4. Déjeant-Pons, M. The European landscape convention. Landsc. Res. 2006, 31, 363-384. [CrossRef]

5. Gustafson, E. Pattern: What is the state of the art? Ecosystems 1998, 1, 143-156. [CrossRef]

6. Dadashpoor, H.; Salarian, F. Urban sprawl on natural lands: Analyzing and predicting the trend of land use changes and sprawl in Mazandaran city region, Iran. Environ. Dev. Sustain. 2018, 22, 593-614. [CrossRef]

7. Dadashpoor, H.; Zarei, A. Analysis of human drivers of land use changes in Chaloos County, Iran. Geogr. Plan. Space Q. J. 2016, 6, 17-34. 
8. Tanner, E.P.; Fuhlendorf, S.D. Impact of an agri-environmental scheme on landscape patterns. Ecol. Indic. 2018, 85, 956-965. [CrossRef]

9. Pickard, B.R.; Van Berkel, D.; Petrasova, A.; Meentemeyer, R.K. Forecasts of urbanization scenarios reveal trade-offs between landscape change and ecosystem services. Landsc. Ecol. 2017, 32, 617-634. [CrossRef]

10. Vaz, E.; Taubenböck, H.; Kotha, M.; Arsanjani, J.J. Urban change in Goa, India. Habitat Int. 2017, 68, $24-29$. [CrossRef]

11. Vaz, E.; Nijkamp, P. Gravitational forces in the spatial impacts of urban sprawl: An investigation of the region of Veneto, Italy. Habitat Int. 2015, 45, 99-105. [CrossRef]

12. Vaz, E.; De Noronha, T.; Nijkamp, P. Exploratory landscape metrics for agricultural sustainability. Agroecol. Sustain. Food Syst. 2014, 38, 92-108. [CrossRef]

13. UNICEF. The State of the World's Children. 2012. Available online: https://www.unicef.org/sowc2012/pdfs/ SOWC-2012-DEFINITIONS.pdf (accessed on 19 May 2020).

14. Biggs, R.; Schluter, M.; Biggs, D.; Bohensky, E.L.; BurnSilver, S.; Cundill, G.; Dakos, V.; Daw, T.M.; Evans, L.S.; Kotschy, K.; et al. Toward principles for enhancing the resilience of ecosystem services. Annu. Rev. Environ. Resour. 2012, 37, 421-448. [CrossRef]

15. Lerner, A.M.; Eakin, H. An obsolete dichotomy? Rethinking the rural-urban interface in terms of food security and production in the global south. Geogr. J. 2011, 177, 311-320. [CrossRef] [PubMed]

16. Madsen, M.F.; Kristensen, S.B.P.; Fertner, C.; Busck, A.G.; Jørgensen, G. Urbanisation of rural areas: A case study from Jutland, Denmark. Dan. J. Geogr. 2010, 110, 47-63. [CrossRef]

17. Gar-On Yeh, A.; Li, X. Economic development and agricultural land loss in the Pearl River Delta, China. Habitat Int. 1999, 23, 373-390. [CrossRef]

18. Vaz, E.; Painho, M.; Nijkamp, P. Linking agricultural policies with decision-making: A spatial approach. Eur. Plan. Stud. 2015, 23, 733-745. [CrossRef]

19. Vaz, E. Archaeological sites in small towns-A sustainability assessment of Northumberland County. Sustainability 2020, 12, 2018. [CrossRef]

20. Girma, H.M.; Hassan, R.M. Drivers of land-use change in the southern nations, nationalities and people's region of Ethiopia. Afr. J. Agric. Res. Econ. 2014, 9, 148-164.

21. Verburg, P.H.; Chen, Y.; Soepboer, W.; Veldkamp, T.A. GIS-based modeling of human-environment interactions for natural resource management applications in Asia. In Proceedings of the 4th International Conference on Integrating GIS and Environmental Modelling (GIS/EM4): Problems, Prospects and Research Needs, Banff, AB, Canada, 2-8 September 2000.

22. Turner, M.G. Spatial and temporal analysis of landscape patterns. Landsc. Ecol. 1990, 4, 21-30. [CrossRef]

23. Wood, R.; Handley, J. Landscape dynamics and the management of change. Landsc. Res. 2001, 26, 45-54. [CrossRef]

24. Firmino, A. Agriculture and landscape in Portugal. Landsc. Urban Plan. 1999, 46, 83-91. [CrossRef]

25. Wu, Q.; Guo, F.; Li, H.; Kang, J. Measuring landscape pattern in three-dimensional space. Landsc. Urban Plan. 2017, 167, 49-59. [CrossRef]

26. Peng, J.; Wang, Y.; Zhang, Y.; Wu, J.; Li, W.; Li, Y. Evaluating the effectiveness of landscape metrics in quantifying spatial patterns. Ecol. Indic. 2010, 10, 217-223. [CrossRef]

27. Herold, M.; Scepan, L.; Clarke, K.C. The use of remote sensing and landscape metrics to describe structures and changes in urban land uses. Environ. Plan. A 2002, 34, 1443-1458. [CrossRef]

28. Deng, J.S.; Wang, K.; Hong, Y.; Qi, J.G. Spatio-temporal dynamics and evolution of land use change and landscape pattern in response to rapid urbanization. Landsc. Urban Plan. 2009, 92, 187-198. [CrossRef]

29. Feng, Y.; Liu, Y.; Tong, X. Comparison of metaheuristic cellular automata models: A case study of dynamic land use simulation in the Yangtze River Delta. Comput. Environ. Urban Syst. 2018, 70, 138-150. [CrossRef]

30. Steiniger, S.; Hay, G.J. Free and open source geographic information tools for landscape ecology. Ecol. Inform. 2009, 4, 183-195. [CrossRef]

31. Vaz, E. Managing urban coastal areas through landscape metrics: An assessment of Mumbai's mangrove system. Ocean Coast. Manag. 2014, 98, 27-37. [CrossRef]

32. Jiang, L.; Deng, X.Z.; Seto, K.C. The impact of urban expansion on agricultural land use intensity in China. Land Use Policy 2013, 35, 33-39. [CrossRef] 
33. Martellozo, F.; Ramankutty, N.; Hall, R.J.; Price, D.; Purdy, B.; Friedl, M. Urbanization and the loss of prime farmland: A case study in the Calgary-Edmonton Corridor of Alberta. Reg. Environ. Chang. 2014, 15, 881-893. [CrossRef]

34. Alphan, H. Land-use change and urbanization of Adana, Turkey. Land Degrad. Dev. 2003, 14, 575-586. [CrossRef]

35. Wang, X.H.; Zheng, D.; She, Y.C. Land use change and its driving forces on the Tibetan Plateau during 1990-2000. Catena 2008, 72, 56-66. [CrossRef]

36. Xu, C.; Liu, M.; An, S.; Chen, J.M.; Yan, P. Assessing the impact of urbanization on regional net primary productivity in Jiangyin County, China. J. Environ. Manag. 2007, 85, 597-606. [CrossRef]

37. Lu, Q.S.; Liang, F.Y.; Bi, X.L.; Duffy, R.; Zhao, Z.P. Effects of urbanization and industrialization on agricultural land use in Shandong Peninsula of China. Ecol. Indic. 2011, 11, 1710-1714. [CrossRef]

38. Xu, Y.Q.; Li, X.B. Dynamic change of land use in Hebei Southern Plain based on GIS. Resour. Sci. 2003, 25, 77-84.

39. Zhang, Y.P.; Sun, Y.; Wang, X.L.; Cai, Y.P. Study on the driving force of land use change at different scales-A case study of the Xinbei District of Changzhou City. Res. Soil Water Conserv. 2012, 19, 111-116.

40. Reitalu, T.; Sykes, M.T.; Johansson, L.J.; Lönn, M.; Hall, K.; Vandewalle, M.; Prentice, H.C. Small-scale plant species richness and evenness in semi-natural grasslands respond differently to habitat fragmentation. Biol. Conserv. 2009, 142, 899-908. [CrossRef]

41. Natural England. Entry Level Stewardship: Environmental Stewardship Handbook—Fourth Edition. 2013. Available online: http://publications.naturalengland.org.uk/publication/2798159 (accessed on 30 March 2020).

42. Sieber, S.; Amjath-Babu, T.S.; Jansson, T.; Müller, K.; Tscherning, K.; Graef, F.; Pohle, D.; Helming, K.; Rudloff, B.; Saravia-Matus, B.S.; et al. Sustainability impact assessment using integrated meta-modelling: Simulating the reduction of direct support under the EU common agricultural policy (CAP). Land Use Policy 2013, 33, 235-245. [CrossRef]

43. Dekolo, S.; Oduwaye, L.; Nwokoro, I. Urban sprawl and loss of agricultural land in peri-urban areas of Lagos. Reg. Stat. 2015, 5, 20-33. [CrossRef]

44. Olayiwola, A.M.; Igbavboa, E.O. Land use dynamics and expansion of the built-up area in Benin City, Nigeria. Mediterr. J. Soc. Sci. 2014, 5, 2506-2516. [CrossRef]

45. Andren, $\mathrm{H}$. Effects of habitat fragmentation on birds and mammals in landscapes with different proportions of suitable habitat: A review. Oikos 1994, 71, 355-366. [CrossRef]

46. Uuemaa, E.; Antrop, M.; Roosaare, J.; Marja, R.; Mander, U. Landscape metrics and indices: An overview of their use in landscape research. Living Rev. Landsc. Res. 2009, 3, 5-28. [CrossRef]

47. Braimoh, A.K.; Onishi, T. Spatial determinants of urban land use change in Lagos, Nigeria. Land Use Policy 2007, 24, 502-515. [CrossRef]

48. O’Neill, R.V.; Krummel, J.R.; Gardner, R.H.; Sugihara, G.; Jackson, B.; DeAngelis, D.L.; Milne, B.T.; Turner, M.G.; Zygmunt, B.; Christensen, S.W.; et al. Indices of landscape pattern. Landsc. Ecol. 1988, 1, 152-162. [CrossRef]

49. Burel, F.; Baudry, J. Structural dynamic of a hedgerow network landscape in Brittany, France. Landsc. Ecol. 1990, 4, 197-210. [CrossRef]

50. Antrop, M. The transformation of the Mediterranean landscapes: An experience of 25 years of observations. Landsc. Urban Plan. 1993, 24, 3-13. [CrossRef]

51. Ihse, M. Swedish agricultural landscapes-Patterns and changes during the last 50 years, studied by aerial photos. Landsc. Urban Plan. 1995, 31, 21-37. [CrossRef]

52. McGarigal, K.; Marks, B.J. Fragstats: Spatial Pattern Analysis Program for Quantifying Landscape Structure; USDA Forest Service General Technical Report PNW-GTR-351; Pacific Northwest Research Station: Portland, OR, USA, 1995.

53. Mander, U.; Jongman, R.H.G. Human impact on rural landscapes in central and northern Europe. Landsc. Urban Plan. 1998, 41, 149-153. [CrossRef]

54. Fjellstad, W.J.; Dramstad, W.E. Patterns of change in two contrasting Norwegian agricultural landscapes. Landsc. Urban Plan. 1999, 451, 77-191. [CrossRef]

55. Lausch, A.; Herzog, F. Applicability of landscape metrics for the monitoring of landscape change: Issues of scale, resolution and interpretability. Ecol. Indic. 2002, 2, 3-15. [CrossRef] 
56. Crews-Meyer, K.A. Characterizing landscape dynamism using panelled-pattern metrics. Photogramm. Eng. Remote Sens. 2002, 68, 1031-1040.

57. Crews-Meyer, K.A. Agricultural landscape change and stability in northeast Thailand: Historical patch-level analysis. Agric. Ecosyst. Environ. 2004, 101, 155-169. [CrossRef]

58. Southworth, J.; Nagendra, H.; Tucker, C. Fragmentation of a landscape: Incorporating landscape metrics into satellite analyses of land-cover change. Landsc. Res. 2002, 27, 253-269. [CrossRef]

59. Luck, M.; Wu, J. A gradient analysis of urban landscape pattern: A case study from the Phoenix metropolitan region, Arizona, USA. Landsc. Ecol. 2002, 17, 327-339. [CrossRef]

60. Antrop, M.; Eetvelde, V. Holistic aspects of suburban landscapes: Visual image interpretation and landscape metrics. Landsc. Urban Plan. 2000, 50, 43-58. [CrossRef]

61. National Population Commission (NPC). Nigeria National Census 2006; National Population Commission: Abuja, Nigeria, 2007.

62. Rigon, A.; Abah, S.; Dangoji, S.; Walker, J.; Frediani, A.A.; Ogunleye, O.; Hirst, L. Well-Being and Citizenship in Urban Nigeria (Urbanisation Research Nigeria (URN) Research Report); ICF International: London, UK, 2015; p. 52. Available online: http://urn.icfwebservices.com/publications/well-being-and-citizenship-in-urban-nigeria (accessed on 6 March 2020).

63. Filani, M.O. The Changing Face of Lagos: From Vision to Reform and Transformation. Cities Alliance, Brussels. 2012. Available online: http://www.citiesalliance.org/sites/citiesalliance.org/files/Lagos-reformreport-lowres.pdf (accessed on 10 March 2020).

64. Pender, J. Rural population growth, agricultural change and natural resource management in developing countries: The case of fast-growing metropolitan area (Concepcion, Chile). Biol. Conserv. 1999, 127, $272-281$.

65. Madu, I.A. Rural land use changes in southeastern Nigeria: Evidence and environmental consequences. Glob. J. Soc. Sci. 2005, 4, 27-32.

66. Arsanjani, J.J.; Tayyebi, A.; Vaz, E. GlobeLand30 as an alternative fine-scale global land cover map: Challenges, possibilities, and implications for developing countries. Habitat Int. 2016, 55, 25-31. [CrossRef]

67. Han, G.; Chen, J.; He, C.; Li, S.; Wu, H.; Liao, A.; Peng, S. A web-based system for supporting global land cover data production. ISPRS J. Photogramm. Remote Sens. 2015, 103, 66-80. [CrossRef]

68. Chen, J.; Chen, J.; Liao, A.; Cao, X.; Chen, L.; Chen, X.; He, C.; Han, G.; Peng, S.; Lu, M.; et al. Global land cover mapping at $30 \mathrm{~m}$ resolution: A POK-based operational approach. ISPRS J. Photogramm. Remote Sens. 2015, 103, 7-27. [CrossRef]

69. Arsanjani, J.J. Characterizing, monitoring, and simulating land cover dynamics using GlobeLand30: A case study from 2000 to 2030. J. Environ. Manag. 2018, 214, 66-75. [CrossRef] [PubMed]

70. Zhang, Y.; Zhao, L.; Liu, J.; Liu, Y.; Li, C. The impact of land cover change on ecosystem service values in urban agglomerations along the coast of the Bohai Rim, China. Sustainability 2015, 7, 10365-10387. [CrossRef]

71. Zhang, W.; Chen, J.; Liao, A.; Han, G.; Chen, X.; Chen, L.; Peng, S.; Wu, H.; Zhang, J. Geospatial knowledge-based verification and improvement of GlobeLand30. Sci. China Earth Sci. 2016, 59, 1709-1719. [CrossRef]

72. Arowolo, A.O.; Deng, X. Land use/land cover change and statistical modelling of cultivated land change drivers in Nigeria. Reg. Environ. Chang. 2018, 18, 247-259. [CrossRef]

73. McGarigal, K.; Marks, B.J. Fragstats: Spatial Pattern Analysis Program for Quantifying Landscape Structure; Reference Manual; Forest Science Department, Oregon State University: Corvalli, OR, USA, 1994; 62p.

74. Li, H.; Wu, J. Use and misuse of landscape indices. Landsc. Ecol. 2004, 19, 389-399. [CrossRef]

75. Uuemaa, E.; Roosaare, J.; Mander, Ü. Scale dependence of landscape metrics and their indicatory value for nutrient and organic matter losses from catchments. Ecol. Indic. 2005, 5, 350-369. [CrossRef]

76. Turner, M.G.; Gardner, R.H.; O’Neill, R.V. Landscape Ecology in Theory and Practice: Pattern and Process; Springer: New York, NY, USA, 2001.

77. Cushman, S.A.; McGariyal, K.; Neel, M.C. Parsimony in landscape metrics: Strength, universality, and consistency. Ecol. Indic. 2008, 8, 691-703. [CrossRef]

78. Li, H.; Reynolds, J.F. A new contagion index to quantify patterns of landscapes. Landsc. Ecol. 1993, 8, 155-162. [CrossRef]

79. Elkie, P.C.; Rempel, R.S.; Carr, A.P. Patch Analyst User's Manual. Ontario Ministry of Natural Resources; Northwest Science and Technology: Thunder Bay, ON, Canada, 1999; p. 16. 
80. McGarigal, K.; Cushman, S.A.; Ene, E. FRAGSTATS v4: Spatial Pattern Analysis Program for Categorical and Continuous Maps. Available at the Following Web Site: Computer Software Program Produced by the Authors at the University of Massachusetts, Amherst. 2012. Available online: http://www.umass.edu/ landeco/research/fragstats/fragstats.html (accessed on 31 March 2020).

81. McGarigal, K. Fragstats Help. University of Massachusetts, Amherst. 2015. Available online: http://www.umass.edu/landeco/research/fragstats/documents/fragstats.help.4.2.pdf (accessed on 31 March 2020).

82. Geri, F.; Amici, V.; Rocchini, D. Human activity impact on the heterogeneity of a Mediterranean landscape. Appl. Geogr. 2010, 30, 370-379. [CrossRef]

83. Lagos State Government Ministry of the Environment. Tree Planting. Available online: http://moelagos.gov. ng/events/ (accessed on 2 April 2020).

84. Schlesinger, J.; Drescher, A.W. Agricultural land use and the urban-rural gradient: An analysis of landscape metrics in Moshi, Tanzania. Afr. Geogr. Rev. 2018, 37, 14-29. [CrossRef]

85. Foley, J.; DeFries, R.; Asner, G.P.; Barford, C.; Bonan, G.; Carpenter, S.R.; Chapin, F.S.; Coe, M.T.; Daily, G.C.; Gibbs, H.K.; et al. Global consequences of land use. Science 2005, 309, 570-574. [CrossRef] [PubMed]

86. Liu, H.; Weng, Q. Landscape metrics for analysing urbanization-induced land use and land cover changes. Geocarto Int. 2013, 28, 582-593. [CrossRef]

87. Awoniran, D.R.; Adewole, M.B.; Salami, A.T. Wetland conversion and fragmentation pattern with its impacts on soil in the Lower Ogun River Basin. Ife Res. Publ. Geogr. 2011, 10, 125-133.

88. Brady, R.F.; Tobias, T.; Eagles, P.F.J.; Ohrner, R.; Micak, J.; Veale, B.; Dorney, R.S. A typology for the urban ecosystem and its relationship to larger biogeographical landscape units. Urban Ecol. 1979, 4, 11-28. [CrossRef]

89. Baker, L.A.; Hope, D.; Xu, Y.; Edmonds, J.; Lauver, L. Nitrogen balance for the central Arizona-Phoenix (CAP) ecosystem. Ecosystems 2001, 4, 582-602. [CrossRef]

90. Xiao, H.; Liu, Y.; Li, L.; Yu, Z.; Zhang, X. Spatial variability of local rural landscape change under rapid urbanization in Eastern China. ISPRS Int. J. Geo-Inf. 2018, 7, 231. [CrossRef]

91. Sakieh, Y.; Salmanmahiny, A.; Jafarnezhad, J.; Mehri, A.; Kamyab, H.; Galdavi, S. Evaluating the strategy of decentralized urban land-use planning in a developing region. Land Use Policy 2015, 48, 534-551. [CrossRef]

92. Gerger, S.E.; Turner, M.G. Learning Landscape Ecology: A Practical Guide to Concepts and Techniques; Springer: New York, NY, USA, 2002.

93. Vaz, E. (Ed.) Regional Intelligence: Spatial Analysis and Anthropogenic Regional Challenges in the Digital Age; Springer International Publishing AG: Berlin/Heidelberg, Germany, 2020.

94. Vaz, E. The future of landscapes and habitats: The regional science contribution to the understanding of geographical space. Habitat Int. 2016, 51, 70-78. [CrossRef]

95. Jaafari, S.; Sakieh, Y.; Shabani, A.A.; Danehkar, A.; Nazarisamani, A.-A. Landscape change assessment of reservation areas using remote sensing and landscape metrics (case study: Jajroud reservation, Iran). Environ. Dev. Sustain. 2016, 18, 1701-1717. [CrossRef]

(C) 2020 by the authors. Licensee MDPI, Basel, Switzerland. This article is an open access article distributed under the terms and conditions of the Creative Commons Attribution (CC BY) license (http://creativecommons.org/licenses/by/4.0/). 